\title{
Environmental Regulations and Corporate Green Investment: Evidence From Heavy Polluting Companies in China
}

\author{
Crystal Xiaobei Chen ${ }^{1, \mathrm{a}}$, Regina Fangying Lin ${ }^{1, \mathrm{~b}}$, Xinqian Zheng ${ }^{1, \mathrm{c}}$, Yiyuan $\mathrm{Li}^{1, \mathrm{~d}}$ \\ ${ }^{1}$ School of Economics and Management, Harbin Institute of Technology, Shenzhen, China
}

\begin{abstract}
With the rapid development of the global economy, environmental pollution has become one of the main problems facing. As the main carriers of social production, companies create value for the whole society and also occupy the main resources. Heavy polluting companies have serious pollution discharge. They should bear more environmental protection responsibilities. Green investment of heavy polluting companies is the focus of social concern. Therefore, this paper selects 243 listed companies in China's heavy polluting industry as samples to explore the impact of environmental regulations on corporate green investment. This study calculates the green investment amount of companies through the "content analysis method", and divides the environmental regulation into formal environmental regulation and informal environmental regulation. A fixed panel model is constructed for research. The empirical results show that market-incentive environmental regulation and informal environmental regulation have a significantly positive impact on corporate green investment. There is no significant relationship between command-andcontrol environmental regulation and corporate green investment. According to this conclusion, this paper proposes some suggestions about green finance.
\end{abstract}

\section{Introduction}

Since the reform and opening-up, China's economy has maintained stable and rapid growth, but behind the economic growth are excessive resource consumption and serious industrial pollution as well as the continuous deterioration of the ecological environment. In either developed or developing countries, environmental regulation is the preferred tool for environmental governance. According to the experience of the leading countries, environmental regulation will influence all aspects of the economy, industrial structure, and enterprise innovation. In this situation, environmental regulations will inevitably affect the daily production and management activities, environmental governance, and green investment of heavy polluting companies.

Some scholars believe that corporate pollution has a large negative externality, and the supervision of corporate green investment is mainly undertaken and implemented by the government. Currently, corporate green investment of enterprises is mainly characterized by "government regulation" [1]. Many studies have found environmental regulations have a significant impact on corporate green investment, and governments urge companies to consider environmental issues and take green investment into their development strategies [2-5]. Under the pressure of strict environmental regulations and formal media reports and supervision, companies will gradually carry out spontaneous green investment behaviors. Environmental regulations can promote an increase in the scale of corporate green investment [6-10]. Studies also confirm that if the government does not issue relevant environmental regulatory policies and economic incentives, heavy polluting companies will not invest in pollution control [11]. Some scholars believe that combining different types of environmental regulations can better enhance the enthusiasm of enterprises to take environmental protection behaviors [12]. The supervision and management of the public have a positive effect on guiding firms to practice ecological and environmental protection behaviors [13]. But some researches have shown that environmental regulations and corporate green investment are negatively correlated. Purchasing pollution control facilities and improving environmental protection technologies will result in a reduction in liquidity, making it difficult for companies to obtain profits from green investments and reducing their enthusiasm for participating in environmental governance. Therefore, environmental regulations will inhibit corporate green investment [14-16]. In addition, some scholars find that there is a threshold relationship between environmental regulations and corporate green investment, that is, environmental regulations will first have a positive impact on corporate green investment, and then turn into a negative impact [17].

By summarizing relevant literature, it can be concluded that there is indeed a certain relationship between environmental regulation and corporate green investment, and many scholars have carried out some researches on the influence mechanism between them. But they do not reach a consensus on whether 
environmental regulations will promote firms to increase green investment, and their conclusions of positive correlation, negative correlation, and non-linear correlation have been confirmed within a certain range. Therefore, further empirical evidence is needed to test the relationship. Moreover, there is less empirical research on the impact of different types of environmental regulations on corporate green investment.

This paper will select the green investment behavior of heavy polluting companies as the research objects and explore the influence mechanism of environmental regulations on the green investment behavior of heavy polluting companies in China. The main contributions are summarized in two aspects:

On one hand, there is no uniform and recognized standard for the disclosure of corporate green investment in China, so it is difficult to collect the relevant data. This study uses the "content analysis method" and combines the ESG evaluation system of listed companies to build evaluation indexes and score CSR reports and sustainable development reports qualitatively and quantitatively. On the other hand, this paper innovatively discusses the impact of different types of environmental regulations on the green investment of heavy polluting companies and fills up the gap in this field.

\section{Hypothesis}

Market incentives environmental regulation means that government will invest budget in pollution control costs each year. According to the theory of signal transmission, if enterprises realize that governments increase investment to improve environmental governance, enterprises will take action to enhance green investment spontaneously after judging based on the costs and benefits. It gives place to hypothesis 1 as follows:

H1: Market incentive environmental regulation can promote corporate green investment.

Command-and-control environmental regulation refers to the relevant laws, regulations, and policies on environmental protection issued every year by the government department or environmental protection agency where the enterprise is located. Mandatory is the main feature of command-and-control environmental regulation. It can be inferred that enterprises will choose to increase green investment to reduce the possible operating costs when command-and-control environmental regulations are strengthened. So we come to hypothesis 2 :

$\mathrm{H} 2$ : Command-and-control environmental regulation can promote corporate green investment.

Informal environmental regulation can influence the decision-making of enterprises and urge them to implement strategies related to environmental protection, energy conservation, and emission reduction. Green investment may become one of the tools for many heavily polluting enterprises to cope with social public pressure. The green investment behavior of heavy polluting companies can quickly be recognized by the public, satisfy the public's demand and maintain a good reputation. It gives place to hypothesis 3 as follows:
H3: Informal environmental regulation can promote corporate green investment.

\section{Data and method}

\subsection{Samples}

Based on the availability of data, this paper takes 243 Ashare listed companies for the period 2008-2016 in the heavy pollution industry in China as research samples, excluding the stocks of ST, ${ }^{*} \mathrm{ST}$, and samples with missing financial data. The data of corporate green investment is collected from CSR reports and sustainable development reports. The data of environmental regulations come from the "China Statistical Yearbook on Environment" and "China Statistical Yearbook". Other data are obtained from CSMAR and Wind.

\subsection{Variables}

\subsubsection{Dependent variables}

The dependent variable of this research is enterprise green investment (EI). It is graded based on the "content analysis method" and ESG files [18]. Green investment in the CSR report is divided into six types: environmental governance investment, environmental pollution investment, saving resources investment, climate change investment, environmental business investment, and enterprise environmental protection system investment. Every kind of investment has corresponding secondary indexes. Six types of subdivided investment were scored objectively, with each item assigned a score of $0-3$, representing no investment, less investment, medium investment, and sufficient investment, respectively. Finally, the scores of the enterprise under different indicators in each year are added to obtain the total green investment score of the company, which is used to measure the corporate green investment.

\subsubsection{Independent variables}

Based on the studies [19-20], this paper measures market incentive environmental regulation (MBR) from the perspective of governments' environmental protection investment. The total number of new environmental protection regulations issued each year by the local government is used to measure command-and-control environmental regulation (CCR) from the perspective of environmental legislation. Income, education level, population density, and age structure in the location of heavy polluting companies are selected by informal environmental regulation to make a comprehensive score by entropy weight method. The specific definition is shown in Table 1. 


\subsubsection{Control variables}

Control variables include cash holdings, capital structure, investment opportunity, firm size, and corporate profitability.

First, cash holdings are liquid cash assets. Companies need to maintain sufficient cash balance to reduce or avoid operational risks and financial risks. The larger the cash holdings, the larger the green investment scale of enterprises, and vice versa. Second, capital structure plays an important role in operations and growth. When a company has a high liabilities to assets ratio, it means the financial risk is increased. The liability ratio will influence the scale of corporate green investment. Third, companies with high growth will face more changes and challenges, and they need to grasp investment opportunities promptly, which means that companies may face more high-quality investment projects. Therefore, the possibility of corporate green investment is improved. Fourth, firm size is an important factor affecting corporate green investment. Large companies have a wider range of business areas and are more resilient to risks than small companies. The large green investment scale always happens in large companies. Finally, corporate profitability shows that the company has less operating pressure. It does pay more attention to the long-term development and social image. Companies with strong profitability often attach great importance to green investment.

Table 1. Definition of all variables.

\begin{tabular}{|c|c|l|}
\hline Types & Symbol & \multicolumn{1}{|c|}{ Descriptions } \\
\hline $\begin{array}{c}\text { Dependent } \\
\text { variable }\end{array}$ & EI & $\begin{array}{l}\text { Green investment score under the } \\
\text { content analysis method }\end{array}$ \\
\hline \multirow{4}{*}{$\begin{array}{c}\text { Independent } \\
\text { variable }\end{array}$} & MBR & $\begin{array}{l}\text { Natural logarithm of governments' } \\
\text { environmental investment }\end{array}$ \\
\cline { 2 - 3 } & CCR & $\begin{array}{l}\text { Number of newly promulgated } \\
\text { environmental protection legislation }\end{array}$ \\
\cline { 2 - 3 } & IER & $\begin{array}{l}\text { Scores of income, education level, } \\
\text { population density, and age } \\
\text { structure calculated by entropy } \\
\text { method }\end{array}$ \\
\hline \multirow{4}{*}{$\begin{array}{c}\text { Control } \\
\text { variable }\end{array}$} & Cash & The ratio of total cash to total assets \\
\cline { 2 - 3 } & Tev & The ratio of total debt to total assets \\
\cline { 2 - 3 } & Size & Tobin Q value \\
\cline { 2 - 3 } & ROA & $\begin{array}{l}\text { The ratio of net income to the } \\
\text { average total assets }\end{array}$ \\
\hline
\end{tabular}

\subsection{Models}

In order to study the impact of three types of environmental regulations on corporate green investment, three fixed effect models are constructed as follows:

$$
\begin{aligned}
& E I=\alpha+\beta_{1} M B R+\sum_{j=5}^{1} \beta_{j} \text { Control }+\sum \text { Industry }+\sum \text { Year }+\varepsilon \\
& E I=\alpha+\beta_{1} C C R+\sum_{j=5}^{1} \beta_{j} \text { Control }+\sum \text { Industry }+\sum \text { Year }+\varepsilon \\
& E I=\alpha+\beta_{1} I E R+\sum_{j=5}^{1} \beta_{j} \text { Control }+\sum \text { Industry }+\sum \text { Year }+\varepsilon
\end{aligned}
$$

\section{Empirical results}

\subsection{Descriptive analysis}

It can be seen from Table 2 that there is still a large gap between heavy polluting enterprises in green investment (EI), with an average value of 9.39 and a standard deviation of 5.33. The average MBR of market incentive environmental regulation (MBR) is 26.328, and the average CCR of command-and-control environmental regulation $(\mathrm{CCR})$ is 2.05 . From the perspective of other control variables, the average corporate profitability (ROA), asset-liability ratio (Lev), investment opportunity (TobinQ), size of total assets (size), and cash holding ratio (Cash) is $0.058,48 \%, 1.59,23.10$ and $13 \%$, respectively.

Table 2. Descriptive statistics.

\begin{tabular}{|c|c|c|c|c|}
\hline Name & Mean & Std. & Min & Max \\
\hline$E I$ & 9.391 & 5.333 & 0 & 35 \\
\hline$M B R$ & 26.328 & 0.7967 & 19.519 & 27.979 \\
\hline$C C R$ & 2.057 & 2.599 & 0 & 19 \\
\hline IER & 40.65 & 13.41 & 13.54 & 76.71 \\
\hline Cash & 0.132 & 0.113 & 0 & 0.740 \\
\hline Lev & 0.481 & 0.199 & 0.0100 & 1.110 \\
\hline Tobin $Q$ & 1.594 & 1.481 & 0.100 & 12.59 \\
\hline Size & 23.10 & 1.525 & 18.76 & 28.51 \\
\hline ROA & 0.0576 & 0.0727 & -0.430 & 0.440 \\
\hline
\end{tabular}

\subsection{Correlation test}

From the results of Table 3, there is a great correlation between independent variables and dependent variables. The correlation among independent variables does not exceed 0.7 , which indicates that the variable selection in this paper is relatively reasonable, and there is no serious

\begin{tabular}{|c|c|c|c|c|}
\hline & EI & MBR & CCR & IER \\
\hline$M B R$ & $0.166^{* * *}$ & & & \\
\hline$C C R$ & 0.041 & 0.029 & & \\
\hline IER & $0.199^{* * *}$ & $0.074^{* * *}$ & 0.023 & \\
\hline Cash & $-0.139^{* * *}$ & $-0.159^{* * *}$ & -0.031 & $-0.083^{* * *}$ \\
\hline Lev & $0.082^{* * *}$ & $0.077^{* * *}$ & 0.005 & 0.004 \\
\hline Tobin $Q$ & $-0.216^{* * *}$ & $-0.213^{* * *}$ & -0.022 & $-0.087^{* * *}$ \\
\hline Size & $0.368^{* * *}$ & $0.174^{* * *}$ & 0.012 & $0.209^{* * *}$ \\
\hline$R O A$ & $-0.081^{* * *}$ & 0.028 & -0.022 & $-0.126^{* * *}$ \\
\hline & Cash & Lev & TobinQ & Size \\
\hline Lev & $-0.540^{* * *}$ & & & \\
\hline Tobin $Q$ & $0.465^{* * *}$ & $-0.549^{* * *}$ & & \\
\hline Size & $-0.320^{* * *}$ & $0.449^{* * *}$ & $-0.511^{\text {*** }}$ & \\
\hline$R O A$ & $0.404^{* * *}$ & $-0.490^{* * *}$ & $0.478^{* * *}$ & $-0.121^{* * *}$ \\
\hline
\end{tabular}
collinearity between them.

Table 3. Correlation test results.

\subsection{Regression analysis}

Table 4-6 and Figure 1 show the regression results of three types of environmental regulations and green investment of heavy polluting companies. First, the coefficient of MBR is 0.999 , which is significant at the 
statistical level of $99 \%$. Market incentive environmental regulation can promote corporate green investment. Second, the correlation coefficient of command-andcontrol environmental regulation (CCR) was 0.0189 , but it was not significant. Third, informal environmental regulation (IER) obtained by entropy weight analysis is positively correlated with green investment at $1 \%$ level.

Market incentive environmental regulation is beneficial to "digest" the cost of environmental regulation. It is mainly through the government's investment in environmental pollution control, aiming to guide enterprises' pollution discharge level with the help of signals, to promote enterprises to achieve the goal of energy conservation and emission reduction.

However, the command-and-control environmental regulation is mainly manifested in tough rules and regulations. Government regulations need higher supervising requirements. The "one-size-fits-all" approach is less efficient in promoting cleaner production of heavy polluting companies.

Under the influence of informal environmental regulation, heavy polluting companies can satisfy the environmental protection requirements of the public by green investment, which sends a positive signal of taking the initiative to bear social responsibility and maintain the reputation of companies.

Table 4. Regression results of model(1).

\begin{tabular}{|c|c|c|}
\hline & Coefficients & t-statistics \\
\hline MBR & $0.999^{* * *}$ & $(0.210)$ \\
\hline Cash & 1.004 & $(1.288)$ \\
\hline Lev & 0.499 & $(1.431)$ \\
\hline Tobin $Q$ & 0.0196 & $(0.0860)$ \\
\hline Size & $2.455^{* * *}$ & $(0.373)$ \\
\hline ROA & 1.862 & $(2.476)$ \\
\hline Constant & $73.43^{* * *}$ & $(9.871)$ \\
\hline Industry & \multicolumn{2}{|c|}{ control } \\
\hline Year & \multicolumn{2}{|c|}{ control } \\
\hline Number of observations & \multicolumn{2}{|c|}{0.1319} \\
\hline Within $R^{2}$ & \multicolumn{2}{|c|}{${ }^{* *}$} \\
\hline t-statistics in parentheses ${ }^{* * *} p<0.01,{ }^{*} p<0.05,{ }^{*} p<0.1$
\end{tabular}

Table 5. Regression results of model(2).

\begin{tabular}{|c|c|c|}
\hline & Coefficients & t-statistics \\
\hline$C C R$ & 0.0189 & $(0.0384)$ \\
\hline Cash & 1.994 & $(1.274)$ \\
\hline Lev & 0.933 & $(1.402)$ \\
\hline Tobin $Q$ & 0.00846 & $(0.0911)$ \\
\hline Size & $2.868^{* * *}$ & $(0.357)$ \\
\hline$R O A$ & 1.296 & $(2.497)$ \\
\hline Constant & $56.32^{* * *}$ & $(8.399)$ \\
\hline Industry & \multicolumn{2}{|c|}{ control } \\
\hline Year & \multicolumn{2}{|c|}{ control } \\
\hline Number of observations & \multicolumn{2}{|c|}{1319} \\
\hline Within $R^{2}$ & \multicolumn{2}{|c|}{0.140} \\
\hline
\end{tabular}




\section{Acknowledgments}

This paper is supported by Science and Technology Innovation Committee of Shenzhen Municipality. Name of the Project: Research on Happy City in Greater Pearl River Delta. 2020.05-2022.05. RMB 400K. PM. Ongoing. NO. JCY20190806144609107.

\section{References}

1. Pigou A C. (1920) The Economic of Welfare. Macmillan, London.

2. Steadman M E, Zimmerer T W, Green R F. (1995) Pressures from stakeholders hit Japanese companies. Long Range Planning, 28: 29-37.

3. Jaffe A B. (1995) Environmental regulation and the competitiveness of U.S. manufacturing: what does the evidence tell us?[J]. Journal of Economic Literature, 33: 132-163.

4. Henriques I, Sadorsky P. (1996) The determinants of an environmentally responsive firm: an empirical approach. Journal of Environmental Economics \& Management, 3: 381-395.

5. Gray W B, Shadhegian R J. (1998) Environmental regulation investment timing and technology choice. The Journal of Industrial Economic, 46: 235-256.

6. Olson M K. (1999) Agency rulemaking, political influences, regulation, and industry compliance. Journal of Law Economics \& Organization, 15: 573601.

7. Cormier D, Gordon I M, Magnan M. (2004) Corporate environmental disclosure: contrasting management's perceptions with reality. Journal of Business Ethics, 49: 143-165.

8. Maxwell J W, Decker C S. (2006) Voluntary environmental investment and responsive regulation. Environmental \& Resource Economic, 33: 425-439.

9. Dyck A, Volchkova N, Zingales L. (2008) The corporate governance role of the media: evidence from Russia. Journal of Finance, 3: 1093-1135.

10. Murovec N, Erker R S, Prodan I. (2012) Determinants of environmental investments: testing the structural model. Journal of Cleaner Production, 37: 265-277.

11. Yuan Y J, Geng N H. (2010) The transmission mechanism of environmental policies and sustainable development on environment protect industry of China: based on research of government and pollutant corporation and environment protect corporation. China Industrial Economics, 10: 65-74.

12. Du J G, Chen L, Zhao L. (2015) The simulation research of corporate environmental behavior in the perspective of government regulation. Soft Science, 10: 59-64.

13. Chen W, Dietrich S, Zuo W F. (2003) The greening of industry: a research approach of industrial environmental geography. Geographical Research, 5: 601-608.
14. Sanyal P. (2007) The effect of deregulation on environmental research by electric utilities. Journal of Regulatory Economics, 31: 335 - 353.

15. Saltari E, Giuseppe T. (2011) The effects of environmental policies on the abatement investment decisions of a green firm. Resource and Energy Economics, 33: 478-493.

16. Zhang G F. (2013) Government intervention, environmental pollution and corporate environmental protection investment: evidence from listed companies of heavy pollution industries. Research on Economics and Management, 9: 38-44.

17. Tang G P, Li L H, Wu D J. (2013) Environmental regulation, industry attributes and corporate environmental investment. Accounting Research, 6: 83-89.

18. Zhang J J, Yu L C, Bi Q (2016) Media supervision, environmental regulation and enterprise green investment. Journal of Shanghai university of finance and economics, 18: 91-103.

19. Pargaland S, Wheeler D. (1996) Informal regulation of industrial pollution in developing countries: evidence from Indonesia. Journal of Political Economy, 104: 1314-27.

20. Qiu J L, Pan A L, Zhang G Z (2018) Formal environmental regulation, informal environmental regulation and green merger and acquisition of heavy polluting enterprises. Journal of Guangdong Social Science, 2: 51-55. 